\title{
MAKALAH \\ PENGAMBILAN KEPUTUSAN SEORANG MANAGER TERHADAP PERILAKU KARYAWAN
}

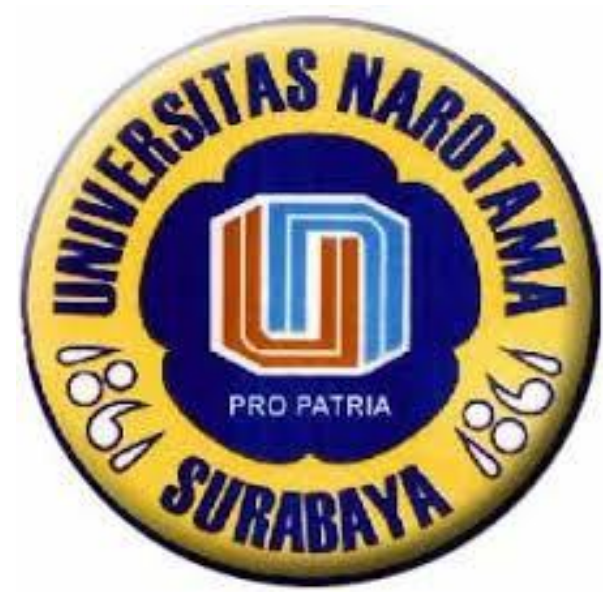

Oleh :

Setiyowati

01214030

Fakultas Ekonomi Manajemen

Universitas Narotama

Surabaya

2017 


\section{BAB I \\ PENDAHULUAN}

\subsection{Latar Belakang}

Dunia bisnis dalam era global ini dihadapkan pada proses perubahan yang begitu cepat dan rumit. Untuk itu kebutuhan akan perubahan yang dinamis dalam berbagai hal seperti visi, misi, tujuan dan sistem berpikir menjadi hal pokok yang harus dimiliki perusahaan. Dalam konteks organisasi belajar, setiap individu organisasi bisnis harus memiliki komitmen dan kapasitas untuk belajar pada setiap tingkat apapun dalam perusahaannya. Sebagai manager bersama karyawan seharusnya terdorong untuk selalu melakukan kajian dengan menghasilkan gagasan-gagasan baru dan mengkontribusikannya pada perusahaan. Manager harus mengambil posisi untuk mencegah terjadinya resiko besar dari suatu kesalahan kerja. Memang suatu keberhasilan biasanya didasarkan pada kegagalan yang pernah dialaminya. Namun manager harus mengevaluasi setiap kegagalan dan melakukan evaluasi diri. Manajemen dan kepemimpinan sangat berbeda, tapi berkaitan. Tugas manager lebih spesifik daripada seorang pemimpin. Kecakapan manajemen, seperti perencanaan dan pendelegasian, lebih konkret jika dibandingkan dengan kecakapan kepemimpinan yang lebih abstrak. Seorang pemimpin lebih mengandalkan pengaruh, inspirasi (ilham), dan kerja sama daripada petunjuk, kebijaksanaan dan prosedur. Kendati demikian, kedua kecakapan tersebut saling melengkapi. Jika seorang pemimpin bisa berbagi visi yang menggiurkan tentang apa yang dapat dicapai organisasi dan bisa menetapkan tujuan dan menjabarkan tugas-tugas yang bisa menggerakkan semua orang ke arah visi itu, maka semua orang akan berprestasi lebih baik. Eksekutif terbaik menguasai kedua kecakapan manajemen dan kepemimpinan. Dalam manajemen setiap orang yang menjadi manager harus juga menjadi seniman. Seniman dalam manajemen adalah orang yang mampu membawa dirinya selaras dengan tugas dan tanggung jawabnya, dan dalam berhadapan dengan orang lain dia dapat bersikap yang sesuai sehingga orang-orang disekitarnya dapat nyaman dan termotivasi jika berada didekatnya. Manager juga seorang ilmuwan, dia harus paham masalah-masalah teknis dalam perusahaan. Bagaimana akuntansi perusahaan berjalan, bagaimana keadaan keuangan perusahaan, bagaimana menyusun strategi perusahaan, tentu semua itu juga membutuhkan ilmu. Seni dan ilmu tak bisa di pisahkan dalam kehidupan seorang manager. manager yang sukses pastilah juga seorang seniman dan juga ilmuwan. 


\subsection{Rumusan Masalah}

1. Bagaimana fungsi dan tujuan manager dalam pengambilan keputusan?

2. Bagaimana peran, sikap dan perilaku manager dalam pengambilan keputusan?

\subsection{Tujuan}

1. Mengetahui tentang fungsi dan tujuan seorang manger

2. Memgetahui tentang seorang manager dalam pengambilan keputusan. 


\section{BAB II \\ TINJAUAN PUSTAKA}

\subsection{Pengertian Pengambilan Keputusan}

Menurut Suharman (2015), pembuatan keputusan atau decision making ialah proses memilih atau menentukan berbagai kemungkiannakemungkinan diantara situasi yang tidak pasti. Pembuatan keputusan tejadi dalam situasi yang meminta seseorang harus membuat prediksi ke depan, ,memilih salah satu diantara dua pilihan atau lebih atau membuat estimasi (perkiraan) mengenai frekuensi kejadian berdasarkan bukti-bukti yang terbatas.

Pengambilan keputusan adalah proses memilih suatu alternative cara bertindak dengan metode yang efisien sesuai situasi (Setiadi 2008:17).

\subsection{Fungsi Pengambilan Keputusan}

Pengambilan keputusan sebagau suatu kelanjutan dari cara pemecahan masalah memiliki fungsi antara lain sebagai berikut.

1. Pangkal permulaan dari semua aktifitas manusia yang sadar dan terarah, baik secara individual maupun secara kelompok, baik secara institusional maupun secara organisasional.

2. Sesuatu yang bersifat futuristik, artinya bersangkut paut dengan hari depan, masa yang akan datang, dimana efeknya atau pengaruhnya berlangsung cukup lama.

\subsection{Tujuan pengambilan keputusan}

1. Tujuan yang bersifat tunggal 
Tujuan pengambilan keputusan yang bersifat tunggal terjadi apabila keputusan yang dihasilkan hanya menyang satu maslah, artinya bahwa sekali diputuskan, tidak akan ada kaitannya dengan masalah lain.

\section{Tujuan yang bersifat ganda}

Tujuan pengambilan keputusanyang bersifat ganda terjadi apabila keputusan yang dihasilkan itu menyangkut lebih dari satu masalah, artinya bahwa satu keputusan yang diambil itu sekaligus memecahkan dua masalah (atau lebih), yang bersifat kontradiktif atau yang bersifat tidak kontradiktif. 


\section{BAB III \\ PEMBAHASAN}

\subsection{Sikap dan Perilaku Manager.}

Berdasarkan sikap dan perilaku para manager internasional dapat dibedakan menjadi beberapa macam, yaitu :

1. Ethnocentric manager / manager etnosentris ethnocentric manager adalah manager yang memiliki anggapan atau persepsi bahwa budaya dan perilaku kerja di negara tempat asalnya jauh lebih baik daripada tempat lain. Contohnya adalah di mana para manager asing lebih suka memberikan kesempatan jenjang karir pada pekerja asing saja sehingga menimbulkan diskriminasi.

2. Polycentric manager / manager polisentris polycentric manager adalah manager yang menggangap bahwa pekerja asing dan pekerja lokal memiliki perbedaan yang cukup jauh dan tenaga kerja dalam negeri lebih memiliki daya saing dan skill di lapangan.

3. Geocentric manager / manager geosentris geocentric manager memiliki suatu anggapan yang lebih realistik dibanding kedua jenis manager di atas. Manager geosentris memahami bahwa terdapat kekurangan dan kelebihan pada budaya yang ada sehingga perlu dibuat adanya penyesuaian budaya dengan memnggabungkan keduanya untuk membentuk budaya yang baru yang lebih kuat dan efektif.

\subsection{Perilaku Manager Terhadap Karyawan}

Ada 5 (lima) perilaku manajer terhadap bawahan yang harus diperhatikan, yaitu :

1. Kalau seorang karyawan tidak tahu apa yang harus dikerjakan, beri dia penjelasan.

2. Kalau seorang karyawan tidak tahu bagaimana cara mengerjakannya, beri dia pelatihan.

3. Kalau seorang karyawan tidak ingin mengerjakannya, beri dia motivasi.

4. Kalau seorang karyawan tahu apa yang harus dikerjakan, berkompetensi dan memiliki motivasi untuk mengerjakannya, beri dia kesempatan 
5. Kalau seorang karyawan sudah mengerjakannya dan memenuhi standar (bahkan melebihi), beri dia penghargaan.

\subsection{Ciri Perilaku Manager yang Tidak Kompeten}

Berikut adalah ciri-ciri manager yang tidak kompeten, dan cenderung beperilaku buruk atau bahkan sadis kepada para bawahannya :

1. Serangan verbal di depan umum bawahannya melukiskan, bagaimana manager mereka cara terus-menerus melakukan teriakan amukan di tempat-tempat umum, dengan maki-makian sebagai senjata utamanya.

2. Pemalsuan catatan para pekerja juga memberikan indikasi, bahwa managermanager sadis tidak merasa segan-segan atau menyesal untuk merobah catatancatatan dan memanipulasikan kegiatan-kegiatan lampau untuk mengubah lingkungan kerja sesuai kepentingan mereka. Mereka sering menyangkal telah memberi perintahperintah langsung kepada bawahan. Dengan demikian menghindari rasa tanggung jawab terhadap hasil-hasil yang negatif. Sambil memanipulasi fakta-fakta, peristiwa, mereka mengaku, bahwa merekalah yang berjasa dan bukan kelompok kerja. Senjata utama mereka adalah sindiran, desas-desus dan menjelekkan orang lain.

3. Kritik tajam dan berlebih-lebihan tema sadisme yang juga selalu muncul adalah mengenai ketajaman dan bentuk kritik yang disampaikan oleh manager sadis. Para pekerja menyebut manager seperti itu "tukang ngoceh abadi". Manager seperti itu secara konsisten mengadakan kritik, tidak perduli apakah perlu di-ambil tindakan tegas atau tidak terhadap bawahan. Tujuannya adalah untuk membeberkan kelemahan dan kesalahan; bukan untuk memperbaikinya. Kritik sering ditancarkan terhadap soal-soal kecil dan tidak berarti dan ditujukan ke $\neg$ pada pribadi pekerja dan bukan terhadap pekerjaan. Para pekerja tidak pernah dapat pengakuan positif.

4. Standar-standar yang tidak jelas kemungkinan terjadinya kritik bertubi-tubi diperkuat oleh ke cenderungan manager sadis untuk tidak mengkomunikasikan standar-standar. Demikian pula kegemarannya terhadap agenda- agenda dan motifmotif yang tidak jelas. Semua faktor ini menghalangi para pekerja untuk cukup 
mengetahui apa yang dikehendaki oleh manager tersebut, sehingga dapat merubah sikap mereka demi tercapainya tujuan-tujuan yang ada.

5. Penyalahgunaan kekuasaan untuk menundukkan bawahan menurut para pekerja, manager sadis sama sekali tidak mentolerir perbedaan faham, pikiran independen serta menuntut kepatuhan dan orang harus selalu setuju dengan pandangannya. Taktik-taktik yang digunakan adalah mengacau atau memberhentikan orang; memblokir usaha-usaha untuk pindah ke pekerjaan lain dan menahan hak hak istimewa yang diberikan secara normal kepada pekerja oleh perusahaan, menerapkan sanksi-sanksi berat dan memecat seenaknya para pekerja.

6. Membuat dan melaksanakan peraturan-peraturan pendekatan manager sadis terhadap peraturan adalah menyesuaikannya dengan keadaan yang berlaku. Mereka jalankan policies serta prosedur-prosedur perusahaan yang sesuai dengan tujuan pribadi mereka. Kalau terjadi hal yang sebaliknya, manager sadis mengabaikan policy atau prosedur. Manager sadis terutama mempersingkat jam istirahat atau justru memperpanjang jam-jam kerja, tanpa memberi uang lembur.

7. Mementingkan diri secara berlebih-lebihan para pekerja menunjukkan, bahwa manager sadis sang atau mementingkan diri; tanpa memperdulikan dampaknya terhadap karyawan atau proyek. Manager sadis tidak menunjukkan loyalitas terhadap bawahan dan sulit dipegang kata-katanya. Sadis-sadis itu menjilat, memberi imbalan kepada kawan-kawan dan melaksanakan tugas-tugas yang bersifat pribadi (bukan demi kepentingan perusahaan) untuk segelintir orang terpilih.

8. Kelakuan tidak tegas dan irasional para pekerja mengatakan, bahwa meskipun para manager sadis suka menyinggung masalah moral, namun tingkah laku mereka tetap sulit diramalkan serta tidak rasional. Beberapa pekerja juga menjelaskan, bahwa manager-manager mereka memperlihatkan gaya tingkah-laku dan "mood" yang berbeda-beda; dan yang lembut sampai yang sangat brutal. 


\section{BAB IV \\ KESIMPULAN}

\subsection{Kesimpulan}

Dari uraian diatas kita tau bahwa sebagai manager bersama karyawan seharusnya terdorong untuk selalu melakukan kajian dengan menghasilkan gagasan-gagasan baru dan mengkontribusikannya pada perusahaan. Seniman dalam manajemen adalah orang yang mampu membawa dirinya selaras dengan tugas dan tanggung jawabnya, dan dalam berhadapan dengan orang lain dia dapat bersikap yang sesuai sehingga orang-orang disekitarnya dapat nyaman dan termotivasi. Manager juga seorang ilmuwan, dia harus paham masalah-masalah teknis dalam perusahaan. Bagaimana akuntansi perusahaan berjalan, bagaimana keadaan keuangan perusahaan, bagaimana menyusun strategi perusahaan, tentu semua itu juga membutuhkan ilmu. Seorang manajer yang professional akan membawa kemajuan dalam suatu perusahaan, sebaliknya jika seorang manager kurang paham apa tugas dan kewajibannya sehingga tidak bisa melakukan pembenahan maka perusahaan akan rugi dan mungkin bisa mengalami kemunduran dan akan berdampak negatif kepada para karyawan/bawahannya. 


\section{DAFTAR PUSTAKA}

Suharman. 2005. Psikologi Kognitif. Surabaya:Srikandi

Nugroho J. Setiadi. 2008. Teori Ekonomi \& Pengambilan Keputusan. Jakarta:Kencana. 
PT. X

Kenjeran Antonio

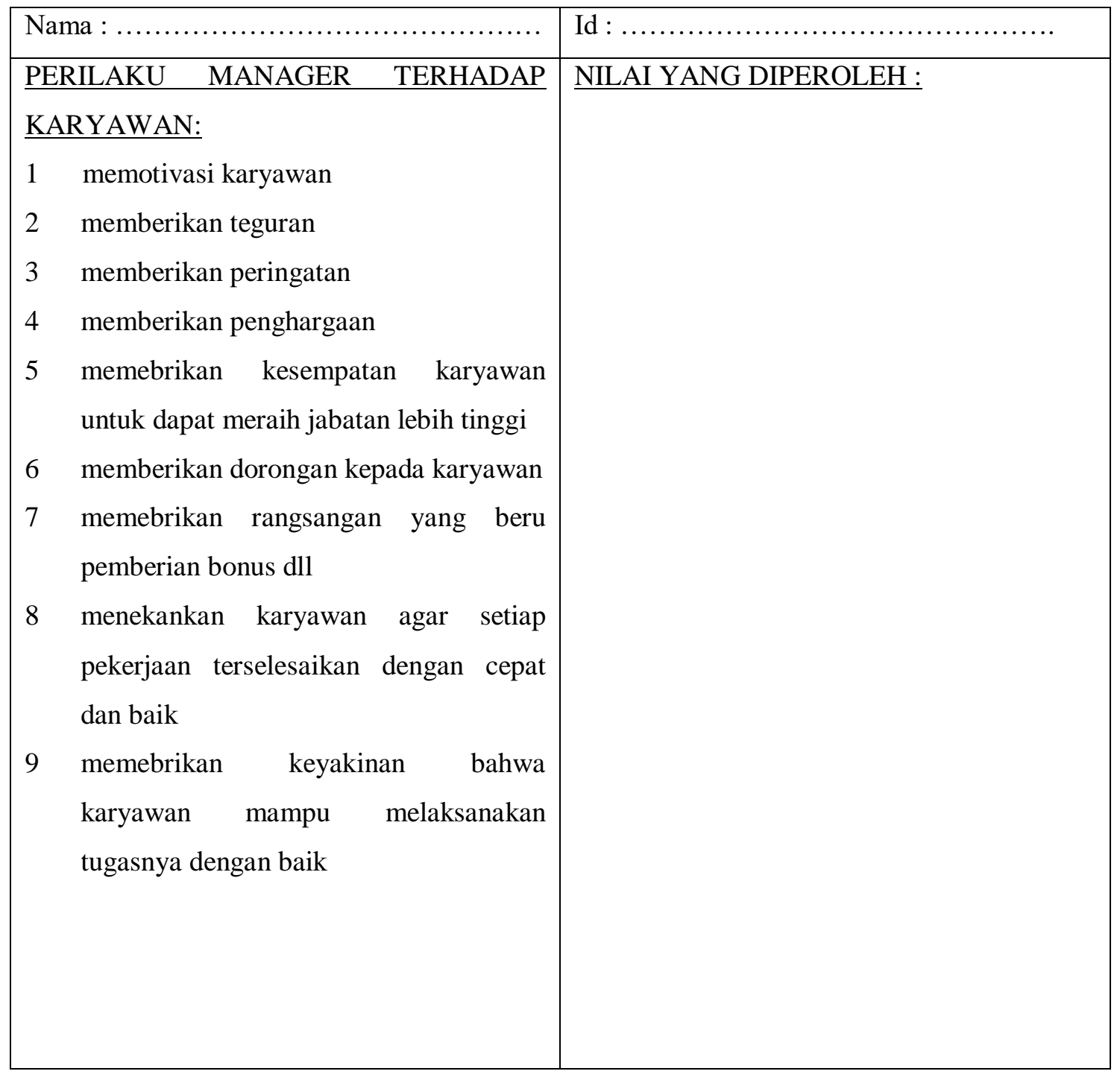

